İş ve İnsan Dergisi I The Journal of Human and Work

Y1l | Year: Nisan | April 2020

Cilt-Sayı | Volume-Issue: 7 (1)

ss I pp: $23-32$

doi: $10.18394 /$ iid. 629970

e-ISSN 2148-967X

https://dergipark.org.tr/tr/pub/iid

Araştırma Makalesi

\title{
Kariyer Hedef Tutarsızlık Ölçeğinin Türkçeye Uyarlanması: Geçerlik ve Güvenirlik Çalışması *
}

\author{
Adaptation of Career Goal Discrepancies Scale to Turkish: Validity and Reliability \\ Study
}

Faruk Caner Yam ${ }^{a}$, Serdar Alkın ${ }^{b}$, Yaşar Barut ${ }^{c}$

MAKALE BILGGISİ

\section{Anahtar Kelimeler:}

Kariyer Hedefi, Tutarsizlık

Kariyer Stresi, Geçerlik,

Güvenirlik, Uyarlama

Tarihler:

Geliş 06 Ekim 2019

Düzeltme geliş 02 Şubat

2020

Kabul 03 Mart 2020

\begin{abstract}
ÖZ
Bu çallşmanın amacı Creed ve Hood (2015) tarafindan geliştirilen Kariyer Hedef Tutarsızlık Ölçeği'nin Türkçeye uyarlanmasıdır. Çalışmada öncelikle ölçeğin Türkçeye çeviri çalışmaları yapılmış ve dil geçerliği test edilmiştir. Çalışma grubunu 147 (\%71) kadın ve 60 (\%29) erkek olmak üzere toplam 207 üniversite öğrencisi oluşturmaktadır. Katılımclların sinıf düzeyleri ise 1 ile 4 arasında $(X=2.64 ; s=1.13)$ değişmektedir. Veriler toplandiktan sonra doğrulayıcı faktör analizi yapılmış $(x 2 / d f=2.37, G F I=.92, I F I=.95, C F I=.95, N F I=.92 A G F I=.87, T L I=$ .93 ve RMSEA =.080) ve ölçeğin güvenirlik analizi için Cronbach's Alfa iç güvenirlik katsayısı $(a=.92)$ hesaplanmıştır. Ölçüt geçerliği için Özden ve Sertel-Berk (2017) tarafindan uyarlanan yirmi madde ve üç alt boyuttan oluşan Kariyer Stresi Ölçeği ile Telef (2013) tarafindan uyarlanan Psikolojik Iyi Oluş Ölçeği kullanılmıştır. Kariyer Hedef Tutarsızlık Ölçeği ile diğer ölçekler arasındaki uyumu test etmek için korelasyon analizi yapılmış ve iki ölçekten alınan puanların uyum sağladı̆̆ı sonucuna ulaşılmıştır. Ölçeğin Türkçe formunun ayırt edici bir şekilde ölçüp yapıp yapmadığı test etmek için \% 27'lik alt-üst grup puan ortalamalarını farkının anlamlı olup olmadığını incelemek için bağımsız gruplar t-testi ile yapılmıştır. Sonuç olarak ölçeğin ayırt edicilik özelliğine sahip olduğu ortaya çıkmıştır. Elde edilen bulgular alan yazın ışı̆̆ında tartışılmış̧tır.
\end{abstract}

\section{ARTICLE INFO}

\section{Keywords:}

Career Goal, Discrepancies, Career Distress, Validity, Reliability, Adaptation

Article history:

Received 06 October 2019 Received in revised form 02

February 2020

Accepted 03 March 2020

\begin{abstract}
A B S T R ACT
The aim of this study is to adapt the Career Goal Discrepancies Scale developed by Creed and Hood (2015) into Turkish language. In the study, first of all, the scale was translated into Turkish and its language validity was tested. After this step, the construct validity of the scale was examined by using confirmatory factor analysis with the data collected from 154 university students. Confirmatory factor analysis was performed $(x 2 / d f=2.37, G F I=.92, I F I=.95, C F I$ $=.95, \mathrm{NFI}=.92 \mathrm{AGFI}=.87, T L I=.93$ ve $R M S E A=.080)$ and the reliability of the scale was assessed through Cronbach's Alpha internal reliability coefficient $(a=.92)$. For the validity of the criteria, Career Stress Scale consisting of twenty items and three sub-dimensions adapted by Özden and Sertel-Berk (2017) and Psychological Well-being Scale adapted by Telef (2013) were used. In order to test the discriminative validity of the Turkish form, the independent groups t-test was used to determine whether the difference of the mean scores of the $27 \%$ subupper group was significant. As a result, it was found that the scale significantly discriminated the two groups. The findings were discussed in the light of the literature.
\end{abstract}

* Bu çalışmanın bir kısmı 05-07 Eylül 2019 tarihleri arasında Amasya Üniversitesi bünyesinde düzenlenene II. Uluslararası Ö̆̆renme, Ögretim ve Eğitim Araştırmaları Kongresi'nde sözlü bildiri olarak sunulmuştur.

a İletişim kurulacak yazar, Öğretim Görevlisi, Gaziosmanpaşa Üniversitesi, Adalet Meslek Yüksek Okulu, Adalet Programı, Tokat, Türkiye.E-mail: farukcaneryam@hotmail.com.ORCID:0000-0001-8392-9576.

${ }^{\mathrm{b}}$ Uzm. Psk. Dan., Tokat Milli Eğitim Müdürlüğ̈̈, Tokat, Türkiye. E-mail: pd.serdaralkin@gmail.com.0RCID: 0000-0001-8934 3007

${ }^{\mathrm{c}}$ Dr. Öğr. Üyesi, Ondokuz Mayıs Üniversitesi, Ë̆itim Fakültesi, Eğitim Bilimleri, Rehberlik ve Psikolojik Danışmanlık Bölümü, Samsun, Türkiye.Email: ybarut@omu.edu.tr.ORCID: 0000-0002-5027-2536 


\section{GİRiş}

Kariyer hedefleri, birey tarafindan gelecekte ulaşılmak istenen kariyer durumlarının iç temsilleri olarak tanımlanmaktadır (Austin \& Vancouver, 1996). Bireyler bu süreç içerisinde kariyerleriyle ilgili çeşitli hedefler belirlemekte, bu hedefleri sürekli olarak düzenlenmekte ve belirlediği hedeflere ulaşmak için çaba sarf etmektedir (Dijksterhuis ve Aarts 2010; Öztemel, 2012). Hedef odaklı bir perspektiften bakıldığında, bireyler bir hedef belirledikten sonra, bilinçli ve bilinçsiz bir şekilde yaptıkları ilerlemeyi izleyerek, hedef ve onunla ilişkili davranışlarını sürekli olarak değerlendirirler (Creed \& Hood, 2015). Yapılan bu değerlendirme birey tarafından bazı iç veya diş standartlarla karşılaştırılmaktadır . Bu kıyaslamanın sonuncunda birey eğer belirlemiş olduğu kariyer hedefine ulaşabileceğini algılarsa çabasını artırarak bu hedefe ulaşmaya çalışır ya da bu hedefi ulaşılamaz olarak algılarsa kariyer hedefinde ayarlamalar yaparak belirlemiş olduğu kariyer hedefi ile bulunduğu konum arasında oluşan farkları yönetmeye çalışırlar (Locke \& Latham, 1990). Bundan dolayı bireyler mevcut kariyer durumları ile gelecekteki kariyer durumları arasındaki tutarsızlıkları sürekli değerlendirme eğilimindedirler. $\mathrm{Bu}$ değerlendirme süreçlerinde herhangi bir tutarsızlık tespit ettiklerinde, bireylerde kariyer hedefleri ile ilgili ayarlama veya savunmaya yönelik süreçler aktif olurken, herhangi bir tutarsızlık algılanmadığında hedef izleme süreci devam etmektedir.

Sosyal bilişsel kariyer teorisine göre seçim hedefleri (örneğin, istenen mesleki yön) ve performans hedefleri (örneğin, istenen seviye, kariyer basamağ1) bireyin hedefe ulaşma konusundaki öz yeterliliğinden etkilenmekte ve birey hedefine ulaşmak için ne kadar enerji harcarsa, algılanan sonuç beklentisi o düzeyde artmaktadır (Bandura \& Locke, 2003; Lent, Brown \& Hackett, 1994). Bireyin kariyer hedefine ulaşmaya yönelik öz yeterlik algısında olumsuz bir durum oluşursa veya kariyer hedeflerine ulaşmasının önünde çeşitli engellerin olduğunu fark ederse, birey ya kariyer hedeflerini destekleyecek beceriler geliştirmeye odaklanabilir (örneğin, yetkinliği ve öz yeterliliği arttırmak) ya da engelleri azaltmanın veya aşmanın yollarını araştırır (Creed \& Hood, 2015). Bu süreçte birey, sürekli olarak kariyer hedeflerini belirlemekte, sosyal çevreden gelen geri bildirimler ve kendi çabalarının sonuçlarını değerlendirerek, geleceğe yönelik kariyer beklentilerini yeniden değerlendirir ve bu bağlamda kendileri için belirlemiş oldukları kariyer hedefler doğrultusunda gerekli düzenlemeleri yapmaktadır.
Kariyer hedef tutarsızlığı, bireyin kariyeri açısından gelecekte bulunmak istediği konum ve ulaşmak istediği kariyer hedefleri ile içinde bulunduğu mevcut kariyer düzeyi arasında oluşan uyumsuzluk ve tutarsızlık olarak tanımlanmaktadır (Carver \& Scheier, 1990; Higgins, 1987). Hedef belirleme teorileri hedef belirleme, ilerleme, izleme, tutarsızlıkları belirleme ve bu farklılıkları yönetme basamaklarını içermektedir. Bireylerin belirlemiş oldukları kariyer hedefleri ve standartları (örneğin, elektrikçi olma hedefi) kariyer süreçlerinin gelişimi açısından birer yol gösterici özelliği taşımaktadır (Higgins, 1987). Birey, belilermiş olduğu kariyer hedeflerine ulaşma düzeyine göre sırasıyla yeni davranışlar ve kazanımlar belirlemekte (örneğin, sıkı çalışmak ve çıraklık eğitimi almak) ve içinde bulunduğu kariyer gelişim düzeyini daha önceden belirlemiş olduğu amaç veya standartlarla karşılaştırmaktadır. Bu karşılaştırmanın sonucunda kariyer hedefleri açısından ne düzeyde ilerleme kaydettikleri hakkından çeşitli yargılarda bulunurlar. Birey kariyeri ile ilgili belirlemiş olduğu bir hedefe hızlı ve kolay bir şekilde ulaştığını algıladığında (yani, hedef çok düşük veya kolay algılanır), daha zor bir hedef belirleyerek çıtayı kendisi için yükseltebilmektedir. Daha yüksek bir kariyer hedefi belirleyen birey ise, geleceğe yönelik kariyer hedeflerini değerlendirme ve düzenlemeye yönelir ancak bu durum yeni hedef tutarsızlıklarının ortaya çıkmasına neden olabilmektedir (Williams, Donovan \& Dodge, 2000).

Bireylerin belirlemiş oldukları kariyer hedefleri ve bunların ulaşılabilir düzeyde olup olmaması yaşanabilecek kariyer hedef tutarsızlığı açısından önemli bir durumdur. Çünkü kariyer hedefleri konusunda tutarsızlık yaşayan lise ve üniversite öğrencileri kariyer planı yapma konusunda zorlanabilmekte ve olumsuz duygular (kayg1 başarısızlık hissi, tükenmişlik, yetersizlik) hissedebilmektedirler (Anderson \& Mounts, 2012; Kerpelman, Pittman \& Lamke, 1997; Williams vd., 2000). Bireylerin hayatlarında önemli bir basamak olan kariyer hedeflerine yönelik yaşamış oldukları gelgitlerin ve tutarsızlıkların belirlenmesinin, onların iyi bir kariyer gelişim süreci geçirmesi açısından önemli olduğu düşülmektedir. Ayrıca erken bir zaman diliminde belirlenecek olan kariyer hedef tutarsılıkları, bireylere yeniden kariyer planlama yapma firsatı sağlayacak ve olası kariyer pişmanlığı ve kariyer başarısızlıklarının önüne geçebilecektir. Türkiye'deki alan yazın incelendiğinde Kariyer Uyum Yetenekleri Ölçeği (Büyükgöze-Kavas, 2014, Kariyer Pişmanlığ Ölçeği (Erdurcan \& Kırdök, 2017), Kariyer Uyumu ve İyimserliği Ölçeği (Zorver ve Korku-Owen, 2011), Kariyer Kararı Ölçeği (Büyükgöze-Kavas, 2012) ve Kariyer Hedef Geri Bildirimi Ölçeği 
(Korkmaz \& Kırdök, 2019) gibi çeşitli ölçme araçları bulunmaktadır. Fakat ülkemizdeki alan yazında bireylerin kariyer hedef tutarsızlıklarını değerlendiren bir ölçme aracına rastlanmamıştır. Bundan dolayı bu çalışmada Creed ve Hood (2015) tarafından geliştirilen Kariyer Hedef Tutarsızlığı Ölçeği' ni Türkçeye uyarlamak amaçlanmıştır. Yapılan bu çalışmanın, kariyer ile ilgili alan yazına, bireylerin kariyer hedef tutarsızlıklarının belirlenmesi konusuna ve bu alanda çalışma yapmayı planlayan araştırmacılara katkı sağlaması beklenmektedir.

\section{YÖNTEM}

\subsection{Calıșma Grubu}

Çalışma Karadeniz Bölgesi'ne yer alan bir ve Güneydoğu Anadolu Bölgesi'nde yer alan bir devlet üniversitesinin öğrencileri üzerinde gerçekleştirilmiştir. Araştırmanın çalışma grubunu 147 (\%71) kadın ve 60 (\%29) erkek olmak üzere toplam 207 üniversite öğrencisi oluşturmaktadır. Katılımcıların sınıf düzeyleri 1 ile 4 arasında $(\bar{X}=$ $2.74 ; \mathrm{s}=1.14)$, yaşları ise 18 ile 25 arasında $(\overline{\mathrm{X}}=$ 21.11; $\mathrm{s}=1.47$ ) değişmektedir.

\subsection{Veri Toplama Araçları}

Araştırmada öğrencilerin yaş, cinsiyet, sınıf düzeyi ve okudukları bölümlere ilişkin soruların yer aldığ kişisel bilgi formu, Kariyer Hedefi Tutarsızlık Ölçeği (KHTÖ), Kariyer Stresi Ölçeği (KSÖ) ve Psikolojik İyi Oluş Ölçeği (PİOÖ) kullanılmıştır.

\subsubsection{Kișisel Bilgi Formu}

Araştırmaya katılan öğrencilerin yaş, cinsiyet, sınıf düzeyi ve okudukları bölümlere ilişkin soruların yer aldığı ve araştırmacılar tarafından geliştirilen formdur.

\subsubsection{Kariyer Hedef Tutarsızlık Ölçeği (KHTÖ)}

Creed \& Hood (2015) tarafindan geliştirilen ölçeğin orijinal formu tek boyut ve 12 maddeden oluşmaktadır. Ölçek yedili likert tipinde hazırlanmıştır. Ölçekte hiç ters madde bulunmamaktadır. Araştırmacılar ölçek geliştirme aşamasında geçerlik çalışmaları için açımlayıcı faktör analizi yapılmışlardır. Analizin sonucuna göre KMO (.96) ve Bartlett' in Küresellik Testi ( $\mathrm{p}<$ .01) sonucuna ulaşılmıştır. İkinci aşamada ise ortaya çıkan yapının geçerliğinin test etmek için doğrulayıcı faktör analizi yapmışla ve bu analiz sonucunda modele uyum indekslerinin (x2/df $=1.95 ; \mathrm{GFI}=.95 ; \mathrm{CFI}=.98 ; \mathrm{RMSEA}=.06$ ) iyi uyum gösteren bir model işaret ettiğini bulmuşladır.
Ayrıca araştırmacılar güvenirlik analizi için iç güvenirlik katsayısı (Cronbach's Alpha) hesaplamışlar ve $\mathrm{a}=.96$ bulunarak ölçümlerin güvenilir olduğu sonucuna ulaşmışlardır.

\subsubsection{Kariyer Stresi Ölçeği (KSÖ)}

Choi ve arkadaşları (2011) tarafindan üniversite öğrencilerinden oluşan örneklem grubu üzerinde geliştirdikleri Kariyer Stresi Ölçeği (KSÖ) bireylerin kariyerleriyle ilgili stres kaynakları ve zorlanmalarını ölçmektedir. Ölçeğin orijinal yapısı dört alt boyut ve 20 maddeden oluşmaktadır. Kariyer Stresi Ölçeği, Özden ve Sertel-Berk (2017) tarafindan Türkçeye uyarlanmıştır. Araştırmacılar uyarlama çalışmasında öncelikli olarak açımlayıcı faktör analizi yapılmışlar, sonuç olarak elde edilen verilerin faktör analizine uygun olduğu sonucuna ulaşılmışlardır(KMO = .93 ve Bartlett'in Küresellik Testi $\left.X^{2}=5801.88, p<.01\right)$. Açımlayıcı faktör analizi sonucunda ölçme aracının dört boyutlu olarak Türkçeye uyarlandığı sonucuna ulaşmışlardır. Ölçeğin Türkçe formu orijinal yapısında olduğu gibi 20 maddeden oluşmaktadır. Ayrıca araştırmacılar uyarlama çalışmasında iç güvenirlik katsayısını (Cronbach's Alfa) $a=.94$ hesaplamıştır. Bu çalışmada da KSÖ’nün iç güvenirlik katsayısı a $=.94$ olarak hesaplanmıştır.

\subsubsection{Psikolojik İyi Oluş Ölçeği (PİÖ̈)}

Diener vd., (2009) tarafından üniversite öğrencileri üzerinde geliştirilen Psikolojik İyi Oluş Ölçeği (PİOÖ) olumlu ilişkiler, yeterlik hisleri, anlamlı ve amaçlı bir yaşama sahip olma gibi insanlar için önemli öğeleri tanımlamaktadır. Ölçeğin orijinal yapısı tek boyut içermekte ve sekiz maddeden oluşmaktadır. Ölçek Telef (2013) tarafından Türkçeye uyarlanmıştır. Araştırmacılar tarafından öncelikle açımlayıcı faktör analizi yapılmış, verilerin faktör analizine uygun olduğu sonucuna ulaşılmıştır (KMO $=.84$ ve Bartlett'in Küresellik Testi $\left.X^{2}=1007.633 ; d f=28\right)$. İkinci aşamada ise ortaya çıkan yapının geçerliğinin test edilmesi için doğrulayıcı faktör analizi yapılmıştır. $\mathrm{Bu}$ analiz sonucu modele ait uyum indekslerinin $\left(x^{2} / \mathrm{df}=4.65\right.$; GFI $=.96$; CFI $=.95$; RMSEA $=.08$ ) iyi uyum gösteren bir model olduğunu ortaya koymaktadır. Ölçek orijinal yapısındaki gibi tek boyutlu olup, sekiz maddeden oluşmaktadır. Ayrıca güvenirlik analizi için iç güvenirlik katsayısı (Cronbach's Alfa) hesaplamış ve $\mathrm{a}=.80$ bulunarak ölçümlerin güvenilir olduğu ortaya koyulmuştur. PİOÖ’nin bu çalışmadaki iç güvenirlik katsayısı $\mathrm{a}=.87$ olarak hesaplanmıştır.

\section{3. Çeviri Çalışması}


Ölçeğin uyarlanma çalı̧̧masına başlanmadan önce ölçeği geliştiren araştırmacılar (Creed \& Hood, 2015) ile e-posta yoluyla iletişime geçilmiş ve uyarlama çalışması için izin alınmıştır. Alınan izinin ardından dil geçerliğini sağlamak amacıyla ölçeğin orijinal formu üç İngilizce uzmanına gönderilmiş ve çevirilerinin yapılması sağlanmıştır. Uzmanlardan gelen çeviriler iki adet alan uzmanına gönderilerek, maddelerin alan yazın açısından uygunluğunun değerlendirilmesi sağlanmıştır. Alan uzmanlarının verdiği dönütlerin incelenmesinin ardından oluşturulan ölçek formu Türkçe dil bilgisi ve anlaşılabilirlik açısından değerlendirilmek üzere Türk Dili ve Edebiyat uzmanı olan iki kişiye gönderilmiştir. Uzmanlardan gelen gelen dönütlerden sonra gerekli düzenlemeler yapılarak ölçeğe son hali verilmiştir. Bu çalışmalardan sonra ölçeğin anlaşılabilirlik testi için hem İngilizce hem de Türkçe ölçek formu her iki dili bilen 15 kişilik bir gruba uygulanmış, iki uygulama arasındaki korelasyon katsayısı incelenmiştir.

\subsection{Verilerin Toplanması}

Ölçme araçları çevrimiçi (online) bir şekilde uygulanmıştır. Uygulama gönüllü biçimde çalışmaya katılmayı isteyen öğrencilere yönelik yapılmıştır.

\subsection{Verilerin Analizi}

Araştırma kapsamında Kariyer Hedefi Tutarsızlık Ölçeği (KHTÖ)' nin yapı geçerliğini test etmek için doğrulayıcı faktör analizi yöntemi kullanılmıştır. (Tabachnick \& Fidell, 2007). Bu yöntemde araştırmacı uyum istatistiklerine göre öngörülen modelin gözlenen değişkenlerle ne derece örtüştüğünü ortaya koymaya çalışır (Şencan, 2005). Doğrulayıc1 faktör analizinde Ki-kare değeri/serbestlik derecesi, GFI, AGFI, CFI, NFI, TLI ve RMSEA uyum indeksleri değerlendirilmiştir. $\mathrm{Bu}$ uyum indekslerinden, TLI, GFI, CFI ve NFI' nin .90' da büyük, AGFI'nin .85 'den büyük ve RMSEA'nın .080 veya .010 'dan küçük olması durumundan elde edilen modelinyapı geçerliğini sağladığı kabul edilmektedir ( $\mathrm{Hu}$ \& Bentler, 1999; Tabachnick \& Fidell, 2007). Ayrica "Ki-kare değeri/serbestlik derecesi $\left(x^{2} / d f\right)$ " uyum indeksinin değeri iki ve altında olduğunda iyi, beş veya altında olduğunda ise kabul edilebilir bir uyumunun olduğuna işaret etmektedir (Meydan \& Şeşen, 2015; Şimşek, 2007).

Diğer açıdan ölçüt-uyum geçerliği için Özden ve Sertel-Berk (2017) tarafindan uyarlanan yirmi madde ve üç alt boyuttan oluşan Kariyer Stresi Ölçeği (KSÖ) ile Telef (2013) tarafından uyarlanan Psikolojik İyi Oluş Ölçeği (PİOÖ) kullanılmıştır. Kariyer Hedefi Tutarsızlı Ölçeği (KHTÖ) ile diğer ölçekler arasındaki uyumu test etmek için korelasyon analizi yapılmıştır. Ayrıca Kariyer Hedefi Tutarsızlık Ölçeği (KHTÖ)'nin Türkçe formunun ayırt edicilik açısından geçerliğini test etmek için \% 27'lik alt-üst grup puan ortalamalarını arasındaki farkın anlamlı olup olmadığı bağımsız gruplar t-testi ile incelenmiştir. Ayrıca iç güvenirlik analiz için Cronbach's Alfa (a) iç tutarlılık katsayısı hesaplanmıştır.

\section{BULGULAR}

Uyarlama çalışması için yapılan geçerlik ve güvenirlik analizlerine ait bulgular sırasıyla verilmiştir. Öncelikle geçerliğe ilişkin bulgulara yer verilmiş; dil geçerliği, yapı geçerliği, ölçüt-uyum geçerliği ve iç ölçüte dayalı geçerlik bulguları eklenmiştir. Sonrasında güvenirlik bulgularına değinilmiştir.

\subsection{KHTÖ’nün Dil Geçerliği}

Dil eşdeğerliği çalışmasını yapmak için ölçeğin hem İngilizce hem de Türkçe ölçek formunu her iki dili bilen 15 kişilik bir gruba uygulanmış, iki uygulama arasindaki korelasyon $(\mathrm{r}=.92 ; \mathrm{p}<.001)$ ve bağımlı t-testi sonuçlarına $(t=.815$; df: $14 \mathrm{p}>$ .05) göre ölçeğin Türkçe formunun anlaşılabilir olduğu sonucuna ulaşılmıştır.

\subsection{KHTÖ’ nün Doğrulayıcı Faktör Analizi}

Kariyer Hedefi Tutarsılılk Ölçeği (KHTÖ)'nin çalışmadaki örneklem gurubu üzerindeki yapısını doğrulamak için doğrulayıcı faktör analizi yapılmıştır. Çalışmalarda doğrulayıcı faktör analizi sonuçlarını geçerli kabul edilebilmesi için modele ait Ki-kare uyum testi, RMSEA, GFI, NFI, CFI ve IFI, AGFI, TLI gibi uyum iyiliği indekslerinin kabul edilebilir ya da mükemmel uyuma sahip olması gerektiğini ifade edilmektedir (Kline, 2005; Tabachnick \& Fidell, 2007) Doğrulayıcı faktör analizi sonucu elde edilen uyum iyiliği indeksleri $\mathrm{x} 2 / \mathrm{df}=2.37, \mathrm{GFI}=.92, \mathrm{IFI}=.95, \mathrm{CFI}=.95, \mathrm{NFI}=$ $.92 \mathrm{AGFI}=.87, \mathrm{TLI}=.93$ ve $\mathrm{RMSEA}=.080$ olarak hesaplanmış ve ölçeğin kabul edilebilir düzeyde uyum sağladığı görülmüştür. Doğrulayıcı faktör analizine ilişkin diyagram Şekil -1'de verilmiştir.

Ayrıca modeldeki bütün yollara ait tüm $t$ değerlerinin $* \mathrm{p}<.001$ düzeyinde anlamlı olduğu görülmüştür. Bununla ilgili sonuç Tablo 1'de sunulmuştur.

\section{3. Ölçüt-Uyum Geçerliği}




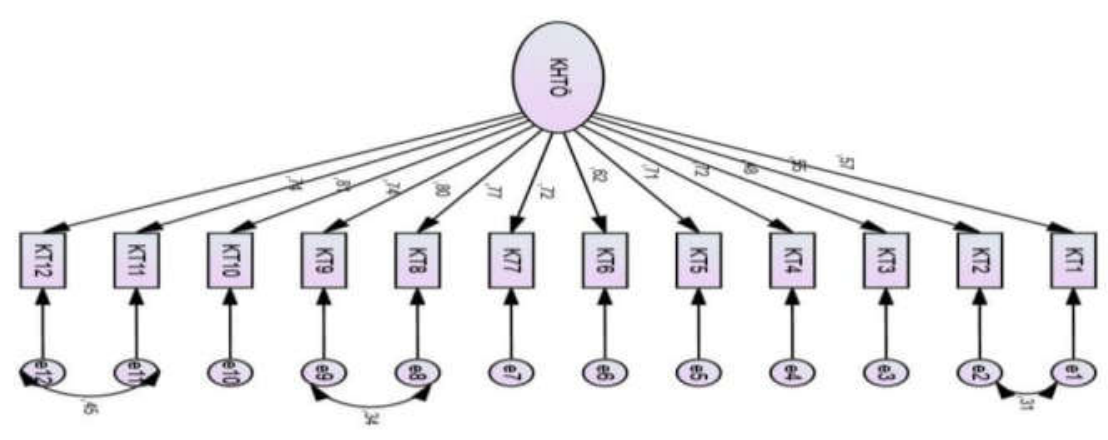

Şekil 1: Kariyer Hedef Tutarsızlığı Ölçeği Path Diyagramı

Ölçeğin ölçüt uyum geçerliğini incelemek için 154 kişiye uygulanan Kariyer Hedefi Tutarsızlığ 1 Ölçeği (KHTÖ) ile Psikolojik İyi Oluş Ölçeği ve Kariyer Stresi Ölçeği (KSÖ)'nin toplam puanı, kariyer belirsizliği ve bilgi eksikliği, dışsal çatışma ve iş bulma baskısı alt boyutları puanları arasındaki ilişki incelemek için Pearson Momentler Çarpımı Korelasyon Katsayısı hesaplanmıştır. Analizin sonucuna göre KHTÖ ile KSÖ nün toplam puanı (r $=.68, \mathrm{p}<.01$ ), kariyer belirsizliği ve bilgi eksikliği alt boyutu $(\mathrm{r}=.66, \mathrm{p}<.01)$, dişsal çatışma alt boyutu $(\mathrm{r}=.47, \mathrm{p}<.01)$ ve iş bulma baskısı $(\mathrm{r}=.60$, $\mathrm{p}<.01)$ ile arasında pozitif yönde anlamlı ilişki görülmüştür. Ayıca Psikolojik İyi Oluş Ölçeği (PİOÖ) ile KHTÖ puanları arasında ise $(r=-.32, p$ $<.01)$ negatif yönde anlamlı ilişki bulunmuştur.
Ölçeğin iç ölçüte dayalı geçerliliğini test etmek için $\% 27$ 'lik alt grup ve üst grup puan ortalamaları arasındaki farkın anlamlı olup olmadığını incelemek için bağımsız t-testi yapılmıştır ve ortalamalar arasındaki farkın $\mathrm{p}<.001$ düzeyinde anlamlı olduğu görülmüştür (xalt $(\mathrm{n}=56)=18.62$, xüst $(\mathrm{n}=56)=$ 54.21; $\mathrm{t}=-32.72$.; $\mathrm{df}=110 ; \mathrm{p}<.001)$.

\subsection{Güvenirlik Çalışması}

Kariyer Hedefi Tutarsızlığı Ölçeği (KHTÖ) için Cronbach lfa katsayısı hesaplanmış ve sonuç olarak $\mathrm{a}=.92$ olarak hesaplanmıştır. Diğer açından ölçeğin madde toplam korelasyon katsayılarının .47 (3. madde) ve .78 (11. madde) arasında değiştiği görülmüştür. $\mathrm{Bu}$ sonuç ölçekteki her maddenin ölçeğin bütünü ile uyum gösterdiğini ortaya koymaktadir.

\section{SONUÇ, TARTIŞMA ve ÖNERİLER}

\subsection{Ayırt Edicilik Geçerliği}

Tablo 1: Modele Ait Yol Katsayıları, $t$ Değerleri ve Anlamlılık Düzeyleri

\begin{tabular}{|c|c|c|c|c|c|}
\hline \multicolumn{3}{|c|}{ Modeldeki Yollar } & \multirow{2}{*}{$\begin{array}{l}\text { Tahmin } \\
1.000\end{array}$} & \multirow[t]{2}{*}{ Standart Hata } & \multirow[t]{2}{*}{ C.R.( $t$ değeri) } \\
\hline KT1 & $<--$ & КHTÖ & & & \\
\hline KT2 & $<---$ & КНTÖ & 1.064 & .136 & $7.847^{*}$ \\
\hline KT3 & $<--$ & КНTÖ & .933 & .158 & $5.915^{*}$ \\
\hline KT4 & $<---$ & КНTÖ & 1.345 & .172 & $7.843^{*}$ \\
\hline KT5 & $<--$ & КHTÖ & 1.437 & .184 & $7.817 *$ \\
\hline KT6 & $<---$ & КНTÖ & 1.252 & .177 & $7.084 *$ \\
\hline K77 & $<--$ & КHTÖ & 1.443 & .184 & $7.824 *$ \\
\hline KT8 & $<--$ & KHTÖ & 1.395 & .171 & $8.172 *$ \\
\hline KT9 & $<--$ & KHTÖ & 1.631 & .195 & $8.358 *$ \\
\hline KT10 & $<--$ & KHTÖ & 1.537 & .193 & $7.976^{*}$ \\
\hline KT11 & $<--$ & KHTÖ & 1.557 & .185 & $8.416^{*}$ \\
\hline KT12 & $<---$ & КНTÖ & 1.398 & .175 & $8.001 *$ \\
\hline
\end{tabular}


Bu çalışmada Creed ve Hood (2015) tarafindan geliştirilen tek boyut ve on iki maddeden oluşan Kariyer Hedef Tutarsızlık Ölçeği'nin geçerlik ve güvenirlik çalışması yapılarak Türkçeye uyarlaması amaçlanmıştır. Dil eşdeğerliği için ölçeğin İngilizce ve Türkçe formları her iki dili bilen belirli bir gruba uygulandiktan sonra iki uygulamadaki puanlar arasındaki korelasyon katsayısının .70-1.00 arasında olması yüksek, .70-.30 arasında olması orta ve .30' dan düşük olması ölçek formları arasında düşük düzeyde bir ilişki olduğuna işaret etmektedir (Büyüköztürk, 2014). Bu çalışmada da ölçeğin İngilizce ve Türkçe formu her iki dili bilen 15 kişilik bir gruba uygulanmıştır. Bu çalışmadaki korelasyon analizi sonucuna göre ölçeğin Türkçe ve İngilizce formları arasında yüksek düzeyde anlamlı ilişkiler olduğu görülmüştür $(\mathrm{r}=.92 ; \mathrm{p}<.001) \mathrm{Bu}$ sonuç doğrultusunda ölçeğin Türkçe formu ile İngilizce formunun okuyuculara aynı anlamı verdiğ $i$ ve dilsel olarak eşdeğer olduğuna işaret ettiği söylenebilir. Çünkü alan yazındaki çeşitli ölçek uyarlama çalışmalarında da iki ölçeğin dilsel açıdan eş değerliklerinin bu şekilde incelendiği görülmektedir (Dağlı ve Baysal, 2016; Telef, 2013). Diğer açıdan iki ölçekte elde edilen puanlarla ilgili yapılan bağımlı $\mathrm{t}$-testi sonucunun $(\mathrm{t}=.815 ; d f: 14 \mathrm{p}$ $>$.05) anlamsız çıkması ölçeğin hem İngilizce hem de Türkçe formunun okuyanlar açısından aynı anlama geldiğini gösteren diğer bir bulgudur.

Kariyer Hedef Tutarsızlığı Ölçeği'nin Türk örneklemi üzerindeki yap1 geçerliğini incelemek için doğrulayıcı faktör analizi yapılmış ancak açımlayıcı faktör analizi uygulanmamıştır. Ölçek uyarlama çalışmalarında başka bir kültürde geliştirilmiş, geçerliği ve güvenirliği test edilmiş bir ölçme aracının yeni bir kültüre uyarlanması yapılmaktadır. Bu noktada yeni bir yapı elde etmek amaçlanmamaktadır (Tabachnick \& Fidell, 2007). Genellikle ölçek geliştirme çalışmalarında tercih edilen açımlayıcı faktör analizi, oluşturulan maddelerden yeni bir yap1 elde etmek amac1 ile kullanılan bir yöntemdir (Seçer, 2018). Mevcut araştırmanın amacına daha uygun olacağından dolayı bu çalışmada doğrulayıcı faktör analizi yöntemi seçilmiştir. Araştırmada yapılan doğrulayıcı faktör analizi sonucunda elde edilen uyum iyiliği değerleri $\left(\mathrm{x}^{2} / d f=2.37, \mathrm{GFI}=.92\right.$, IFI $=$ $.95, \mathrm{CFI}=.95, \mathrm{NFI}=.92 \mathrm{AGFI}=.87, \mathrm{TLI}=.93 \mathrm{ve}$ RMSEA = .080 ) ölçeğin Türkçe formunun yap1 geçerliğini sağladığına işaret etmektedir. Doğrulayıc1 faktör analizine sonucuna göre $\chi 2 / \mathrm{sd}$ değeri önerilen değer aralığını karşılamaktadır (MacCallum, Brown \& Sugawara, 1996). Ayrica ölçeğe ait diğer uyum iyiliği indeksleri, alan yazında önerilen değerler arasında olması yap1 geçerliğini destekleyen bir durumdur $(\mathrm{Hu} \&$
Bentler,1999; MacCallum, Brown \& Sugawara, 1996; Tabachnick \& Fidell 2013). Ölçeğin bu araştırmadaki örneklem grubu üzerinde gerçekleştirilen doğrulayıcı faktör analizi sonuçları, ölçeğin orijinal yapısından elde edilen sonuçlarla $(\chi 2 / \mathrm{sd}=1.95, \mathrm{CFI}=.98, \mathrm{GFI}=.95, \mathrm{RMSEA}=.06)$ benzerlik göstermektedir. Tüm bu sonuçlar ölçeğin yapısının Türk örneklemi üzerinde doğrulandığına işaret etmektedir.

Ölçme araçlarının iç güvenirlik katsayılarının .70 ve üzerinde olması gerektiği ifade edilmektedir (DeVellis, 2012). Kariyer Hedef Tutarsızlı̆̆ Ölçeği'nin Cronbach Alfa iç tutarlık katsayısı a = . 92 olarak hesaplanmış ve bu sonuca göre ölçeğin Türkçe formunun güvenilir sonuçlar verdiği söylenebilir. Ölçeğin orijinal geliştirilme sürecinde araştırmacılar (Creed ve Hood, 2015) ölçeğin iç güvenirlik katsayısı $\mathrm{a}=.95$ olarak hesaplamışlardır. Her iki çalışmada da elde edilen iç güvenirlik katsayılarının birbirine yakın olduğu görülmektedir. $\mathrm{Bu}$ sonuçlar, ölçeğin ileride yapılacak olan başka çalışmalarda güvenilir sonuçlar vereceği ifade edilebilir.

Bir ölçeğin geçerli bir ölçüm yapıp yapmadığının diğer bir göstergesi ölçülmek istenen özellikleri sergileyen bireyler ile bu özellikleri sergilemeyen bireyleri birbirinden ayırt edebilmesidir (Büyüköztürk, 2014). İç ölçüte dayalı bu geçerliliği test etmek için \%27'lik alt grup ve üst grup puan ortalamaları arasındaki farkın manidarlığ bağımsız gruplar $t$-testi analizi ile incelenmiş ve bu analizin sonucuna göre Kariyer Hedef Tutarsızlığı Ölçeği'nin Türkçe formunun ayırt edici bir ölçme aracı olduğu sonucuna ulaşılmıştır $\left(\overline{\mathrm{x}}_{\text {alt }}(\mathrm{n}=56)=18.62\right.$, $\left.\overline{\mathrm{x}}_{\text {ust }(\mathrm{n}=56)}=54.21 ; \mathrm{t}=-32.72 ; d f=110 ; \mathrm{p}<.001\right) . \mathrm{Bu}$ sonuç ölçeğin ölçülmek istenen özellikleri ölçebilme kabiliyetine sahip olduğuna işaret etmektedir.

Ölçeğin ölçüt uyum geçerliğini incelemek için Kariyer Hedefi Tutarsızlığı Ölçeği (KHTÖ) ile Kariyer Stresi Ölçeği (KSÖ)'nin kariyer belirsizliği ve bilgi eksikliği, dışsal çatışma ve iş bulma baskısı alt boyut puanları ile toplam puanı arasındaki ilişki Pearson Momentler Çarpımı Katsayısı hesaplanmıştır. Analizin sonucuna göre KHT ile KSÖ nün toplam puanı $(\mathrm{r}=.68, \mathrm{p}<.01)$, kariyer belirsizliği ve bilgi eksikliği alt boyutu $(\mathrm{r}=.66, \mathrm{p}<$ $.01)$, dişsal çatışma alt boyutu $(\mathrm{r}=.47, \mathrm{p}<.01)$ ve iş bulma baskısı $(\mathrm{r}=.60, \mathrm{p}<.01)$ arasında pozitif yönde anlamlı ilişki görülmüştür. Ayıca Psikolojik İyi Oluş Ölçeği (PİOÖ) ile KHTÖ puanları arasında ise $(r=-.32, p<.01)$ negatif yönde anlamlı ilişki bulunmuştur. Alan yazında doğrudan bu araştırmadaki değişkenlerle ilgili çalışmalar bulunmamasına karşın kariyer kararı ve karasızlığı, kariyer pişmanlığı gibi benzer değişkenlerle ilgili 
çalışmalar bulunmaktadır. Örneğin; Rottinghaus, Jenkins ve Jantzer (2009) yapmış oldukları çalışmalarında kariyer kararı verememiş olan üniversite öğrencilerinin, kariyer kararını vermiş üniversite öğrencilerine göre daha kayg1lı ve stresli oldukları sonucuna ulaşmışlardır. Yine benzer bir çalışmada (Fouad, Guillen, Harris-Hodge, Henry \& Terry, 2006) kariyer kararsızlığ 1 yaşayan bireylerin psikolojik iyi oluşlarının daha düşük olduğu sonucunu rapor etmişledir. $\mathrm{Bu}$ çalışmada ölçüt geceliği için kullanılan psikolojik iyi oluş ölçeği ile kariyer hedef tutarsızlığı arasında da negatif düzeyde anlamlı bir ilişki $(r=-.32, p<.01)$ bulunması bu sonuna benzer bir bulgu olduğu söylenebilir. Çünkü kariyer hedefi belirleme ve kariyer kararı gibi zorlu süreçler üniversite öğrencilerinin psikolojik iyi oluş düzeylerini olumsuz etkileyebilmektedir (Özden \& Sertel-Berk, 2017). Alan yazında bu sonuçları destekleyen ve kariyer süreçleri ile zorlukları konu alan başka çalışmalar da bulunmaktadır (Akkoç, 2012; Bacanlı, Eşici \& Özünlü, 2013; Bacanlı, 2016; Edwards, Hershberger, Russell \& Market, 2001; Gürdoğan \& Atabey, 2015; Multon, Heppner, Gysbers, Zook \& Ellis-Kalton, 2001). Diğer açıdan ölçeğin orijinal geliştirme sürecinde yapılan ölçüt-uyum geçerliği çalışmasında kariyer hedef tutarsızlığı ile kariyer bağlılığı arasından negatif $(\mathrm{r}=.44, \mathrm{p}<.001)$ ve kariyer stresi ile pozitif $(r=.66, p<.001)$ yönde anlamlı ilişki bulunmuştur. Tüm bu sonuçlar Kariyer Hedef Tutarsızlığı Ölçeği (KHTÖ) Türkçe formunun benzer ölçek geçerliğini sağladığına işaret etmektedir.

Diğer açıdan çalışmanın bazı sınırlılıklarından da söz etmek gerekmektedir. Araştırmada veriler toplanırken ölçme araçları internet tabanlı bir hale getirilmiş, katılımcıların bu ölçme araçlarını çevrimiçi olarak doldurmaları sağlanmıştır. Araştırmanın gurubu ölçme araçlarını yanıtlayan 147 kadın ve 60 erkek katılımcıdan oluşmuştur. Cinsiyet açısından ortaya çıkan katılımcı farkı bu araştırmanın bir sınırlılığını oluşturmaktadır. Diğer açıdan bu çalışmanın genellenebilirliği veri toplanan çalışma grubunun evreni ile sınırlıdır. Çalışma ile ilgili yapılacak değerlendirmelerde bu sınırlılık da göz önünde bulundurulmalıdır.

Çalışmanın çeşitli sınırlılıkları olmasına rağmen; doğrulayıcı faktör analizi, güvenirlik analizi ve ölçüt geçerliği sonuçlarına göre Kariyer Hedef Tutarsızlığı Ölçeği'nin yapısı Türk örneklemi üzerinde doğrulanmıştır. $\mathrm{Bu}$ sonuçlar ölçeğin bundan sonraki çalışmalarda geçerli ve güvenilir sonuçlar vereceğine işaret etmektedir. Ayrica alan yazında üniversite öğrencilerinin kariyer gelişimi sırasında kariyer stresi, kariyer kararsızlığ 1 , kariyer pişmanlığı ve kariyer öz yeterlik düşüklüğü gibi çeşitli zorluklar yaşadıklarını belirten çalışmalar bulunmaktadır (Edwards vd., 2001; Fouad vd., 2006; Haase, Hackhausen \& Ko'ller, 2008; Multon vd., 2001; Misra, McKean, West \& Russo, 2000). Üniversite öğrencilerinin kariyer gelişimleri sırasında yaşamış oldukları diğer bir zorluk ise kariyer hedef tutarsızlığıdır (Creed ve Hood, 2015). $\mathrm{Bu}$ çalışmada uyarlanan ölçme aracının üniversite veya bağımsız kuruluşların bünyelerinde bulunan kariyer merkezlerinde kullanılmasının, üniversite öğrencilerinin olası kariyer hedef tutarsızlıklarının erken dönemde belirlenmesi ve çeşitli önlemlerin alınmasına katkı sağlayabileceği düşünülmektedir. Diğer açıdan bireylerdeki kariyer hedef tutarsızlıklarının düzeylerinin yüksek olması, onların psikolojik iyi oluşlarını olumsuz etkileyebilmektedir. Bu çalışmada uyarlanan ölçme arac1 kullanılarak, bireylerdeki kariyer hedef tutarsızlıklarının düzeyleri belirlenerek, buna yönelik çalışmaların yapılmasının, onların psikolojik iyi oluş düzeylerine olumlu katkılar sunması beklenmektedir.

\section{ETIKK BEYANATI}

Destek Bilgisi: Bu çalışmada herhangi bir özel veya resmi bir kuruluştan ya da başka bir organizasyondan destek alınmamıştır.

Çıkar Çatışması: Tüm yazarlar adına, sorumlu yazar çıkar çatışması olmadığını belirtir.

Etik Onayı: İnsan katılımcıları içeren çalışmalarda gerçekleştirilen tüm prosedürler, kurumsal ve / veya ulusal araştırma komitesinin etik standartlarına ve 1964 Helsinki deklarasyonuna ve daha sonraki değişikliklerine veya karşılaştırılabilir etik standartlara uygundur.

Bilgilendirilmiş Onam Formu: Çalışmaya katılan tüm bireylere, araştımanın içeriği ve çalıșmanın gönüllük esasına gore yürütüldüğüne dair bilgilendirilmiş onam formu ile aydınlatılmıştır. 


\section{KAYNAKÇA}

Akkoç, F. (2012). Lise öğrencilerinin mesleki kararsızlıkları ile kariyer inançları arasındaki ilişki. Dokuz Eylül Üniversitesi Buca Eğitim Fakültesi Dergisi, 32, 49-70.

Austin, J. T. \& Vancouver, J. B. (1996). Goal constructs in psychology: Structure, process, and content. Psychological Bulletin, 120, 338-375.

Anderson, K. L. \& Mounts, N. S. (2012). Searching for the self: An identity control theory approach to triggers of occupational exploration. The Journal of Genetic Psychology, 173, 90-111.

Bacanlı, F., Eşici, H. \& Özünlü, M. B. (2013). Kariyer karar verme güçlüklerinin çeşitli değişkenlere göre incelenmesi. Türk Psikolojik Danıșma ve Rehberlik Dergisi, 4(40), 198-211.

Bacanlı, F. (2016). Kariyer karar verme güçlükleri ve meslek seçimine ilişkin akılcı olmayan inançların ilişkisi. Türk Psikolojik Danışma ve Rehberlik Dergisi, 4(37).

Bandura, A. \& Locke, E. A. (2003). Negative selfefficacy and goal effects revisited. Journal of Applied Psychology, 88, 87-99.

Büyükgöze-Kavas, A. (2014). Validation of the Career adapt-abilities scale Turkish form and its relation to hope and optimism. Australian Journal of Career Development, 23(10), 125-132. doi: $10.1177 / 1038416214531931$.

Büyükgöze-Kavas, A. (2012). Turkish adaptation of career decision scale: Validity and reliability study. Türk Psikolojik Danışma ve Rehberlik Dergisi, 4(38), 159-168.

Büyüköztürk, Ş. (2014). Sosyal bilimler için veri analizi el kitabı. Ankara: Pegem Akademi.

Carver, C. S. \& Scheier, M. (1990). Principles of selfregulation: Action and emotion. New York, NY: Guilford Press.

Creed, P. A. \& Hood, M. (2015). The development and initial validation of a scale to assess career goal discrepancies. Journal of Career Assessment, 23(2), 308-317.

Choi, B. Y., Park, H. R., Nam, S. K., Lee, J., ..., \& Lee, S. M. (2011). The development and initial psychometric evaluation of the Korean Career Stress Inventory for college students. Career Development Quarterly, 59, 559-572.

Dağlı, A. \& Baysal, N. (2016). Yaşam doyumu ölçeğinin Türkçe 'ye uyarlanması: Geçerlik ve güvenirlik çalışması. Electronic Journal of Social Sciences, 15(59), 1250-1262.
DeVellis, R. F. (2012). Scale development: Theory and applications (3rd ed.). Thousand Oaks, CA: Sage Publications.

Diener, E., Wirtz, D., Biswas-Diener, R., Tov, W., KimPrieto, C., Choi, D., et al. (2009). New measures of wellbeing. Social Indicators Research Series, 39. Doi: 10.1007/978-90-481-2354-4 12

Dijksterhuis, A. \& Aarts, H. (2010). Goals, attention, and (un)consciousness. Annual Review of Psychology, 61, 467-490.

Edwards, K. J., Hershberger, P. J., Russell, R. K. \& Market, R. J. (2001). Stress, negative social exchange, and health symptoms in university students. Journal of American College Health, 50, 7579 .

Erdurcan, S. \& Kırdök, O. (2017). Mesleki Karar Pişmanlığı Ölçeği: Adaptasyon, Geçerlik ve Güvenirlik Çalışması. Mersin Üniversitesi Ë̆itim Fakültesi Dergisi, 13(3) , 1140-1150. Doi: 10.17860/mersinefd.330880

Fouad, N. A., Guillen, A., Harris-Hodge, E., Henry, C. \& Terry, S. (2006). Need, awareness, and use of career services for college students. Journal of Career Assessment, 14, 407-420.

Gürdoğan, A. \& Atabey, S. (2015). Öğrencilerin meslek stajından memnuniyet düzeylerinin kariyer hedeflerine etkisi. Muğla Sitkı Koçman Üniversitesi Iktisadi ve İdari Bilimler Fakültesi Ekonomi ve Yönetim Araştırmaları Dergisi, 4(1).

Higgins, E. T. (1987). Self-discrepancy: A theory relating self and affect. Psychological Review, 94, 319-340.

Haase, C. M., Heckhausen, J. \& Ko"ller, O. (2008). Goal engagement during the school-work transition: Beneficial for all, particularly for girls. Journal of Research on Adolescence, 18, 671-698.

Hu, L. T. \& Bentler, P. M. (1999). Cut off criteria for fit indices in covariance structure analysis: Conventional criteria versus new alternatives. Structural Equation Modeling, 6, 1-55.

Korkmaz, O. \& Kırdök, O. (2019). Kariyer Hedefi Geribildirim Ölçeği'nin (KHGÖ) Türkçeye Uyarlanması: Geçerlik ve Güvenirlik Çalışması. Kuramsal Ĕ̈itimbilim Dergisi, 12(2) , 494-510 . DOI: 10.30831/akukeg.443315

Kline, R. B. (2005). Principles and practice of structural equations modeling (2nd ed). New York: Guilford.

Kerpelman, J. L., Pittman, J. F. \& Lamke, L. K. (1997). Toward a microprocess perspective on adolescent identity development: An identity control theory approach. Journal of Adolescent Research, 12, 325346. - 
Lent, R.W., Brown, S. D. \& Hackett, G. (1994). Toward a unifying social cognitive theory of career and academic interest, choice, and performance. Journal of Vocational Behavior, 45, 79-122.

Locke, E. A. \& Latham, G. P. (1990). A theory of goal setting and task performance. Englewood Cliffs, NJ: Prentice Hall.

MacCallum, R. C., Brown, M. W. \& Sugawara, H. M. (1996). Power analysis and determination of sample size for covariance structure modeling. Psychological Methods, 1, 130-149.

Meydan, C. H. \& Şeşen, H. (2015). Yapısal eşitlik modeli Amos uygulamaları. Ankara: Detay Yayıncılık.

Misra, R., McKean, M., West, S. \& Russo, T. (2000). Academic stress of college students: Comparison of student and faculty perceptions. College Student Journal, 34, 236-245.

Multon, K. D., Heppner, M. J., Gysbers, N. C., Zook, C. \& Ellis-Kalton, C. A. (2001). Client psychological distress: An important factor in career counseling. Career Development Quarterly, 49, 324-335.

Özden, K. \& Sertel Berk, Ö . (2017). Reliability and Validity Study of Turkish Version of the Korean Career Stress Inventory (KCSI). Psikoloji Çalışmaları Dergisi, 37(1), 35-51.

Öztemel, K. (2012). Kariyer kararsızlığı ile mesleki karar verme öz yetkinlik ve kontrol odağı arasındaki ilişsiler. Gazi Üniversitesi Gazi Eğitim Fakültesi Dergisi, 32(2), 459-477.

Rottinghaus, P. J., Jenkins, N. \& Jantzer, A. M. (2009). Relation of depression and affectivity to career decision status and self-efficacy in college students. Journal of Career Assessment, 17, 271-285.

Seçer, İ. (2018). Psikolojik test geliştirme ve uyarlama süreci: Spss ve lisrel uygulamaları. (2. baskl). Ankara: Anı Yayınları.

Şencan, H. (2005). Sosyal ve davranışsal ölçümlerde güvenilirlik ve geçerlilik. Ankara: Seçkin Yayınevi.

Şimşek, Ö. F. (2007). Yapısal eşitlik modellemesine giriş:(temel ilkeler ve LISREL uygulamaları). Ankara: Ekinoks Yayınevi.

Tabachnick, B. G. \& Fidell, L. S. (2007). Using multivariate statistics. (Fifth edition). Boston: Pearson Education.

Tabachnick, B. G. \& Fidell, L. S. (2013). Using multivariate statistics. (Sixth edition). Boston: Pearson.

Telef, B. B. (2013). Psikolojik İyi Oluş Ölçeği: Türkçeye uyarlama, geçerlik ve güvenirlik çalışması. Hacettepe Üniversitesi Eğitim Fakültesi Dergisi, 28(3), 374-384.
Williams, K. J., Donovan, J. J. \& Dodge, T. L. (2000). Self-regulation of performance: Goal establishment and goal revision processes in athletes. Human Performance, 13, 159-180.

Zorver, C. E. \& Owen, F. K. (2014). Developing a Career Adaptability and Optimism Scale Kariyer Uyumu ve İyimserliği Ölçeği'nin geliştirilmesi. Journal of Human Sciences, 11(2), 314-331. 
Ek 1: Kariyer Hedef Tutarsızlık Ölçeği

\begin{tabular}{|c|c|c|c|c|c|c|c|}
\hline \multicolumn{8}{|c|}{$\begin{array}{l}\text { Sevgili Katılımcılar; } \\
\text { Aşağıda kariyer gelişim süreçleriniz ile ilgili ifadeler verilmiştir. Bu ifadelere katılma düzeyinizi 1-çok az ve 7- } \\
\text { çok fazla olmak üzere size uygun olan düzeyi } 1 \text { ile } 7 \text { arasından bir seçeneği işaretleyerek belirtiniz. }\end{array}$} \\
\hline \multicolumn{8}{|l|}{ Maddeler } \\
\hline $\begin{array}{l}\text { 1.Planlarım gerçekten istediğim kariyeri elde etmem konusunda bana } \\
\text { yardımcı olmuyor/işe yaramıyor. }\end{array}$ & 1 & 2 & 3 & 4 & 5 & 6 & 7 \\
\hline $\begin{array}{l}\text { 2. Bugüne kadar elde ettiğim başarılar, kariyer hedeflerime } \\
\text { ulaşabileceğim konusunda bana güven vermiyor. }\end{array}$ & 1 & 2 & 3 & 4 & 5 & 6 & 7 \\
\hline $\begin{array}{l}\text { 3.Kariyer hedeflerim konusunda ilerleme sağlıyorum, ancak istediğim } \\
\text { kariyeri elde etmek için yeterince başarılı olduğumu düşünmüyorum. }\end{array}$ & 1 & 2 & 3 & 4 & 5 & 6 & 7 \\
\hline $\begin{array}{l}\text { 4.Çok çaba sarf etmeme rağmen, idealimdeki kariyerimi elde } \\
\text { edemeyeceğimi düşünüyorum. }\end{array}$ & 1 & 2 & 3 & 4 & 5 & 6 & 7 \\
\hline $\begin{array}{l}\text { 5.En iyi çabalarımla bile, idealimdeki kariyerimden daha düşük bir } \\
\text { kariyere razı olmak zorunda kalacağımı düşünüyorum. }\end{array}$ & 1 & 2 & 3 & 4 & 5 & 6 & 7 \\
\hline $\begin{array}{l}\text { 6. Çok çalışıyorum fakat yine de bu sürecin gerçekten istediğim } \\
\text { kariyerle sonuçlanacağından şüpheliyim. }\end{array}$ & 1 & 2 & 3 & 4 & 5 & 6 & 7 \\
\hline $\begin{array}{l}\text { 7.İstediğim kariyeri elde etmek için gerekli olan standartları } \\
\text { sağlayacağımdan şüpheliyim. }\end{array}$ & 1 & 2 & 3 & 4 & 5 & 6 & 7 \\
\hline $\begin{array}{l}\text { 8. Belirmiş olduğum kariyer hedefime odaklandım, fakat ona } \\
\text { ulaşabileceğimi sanmıyorum. }\end{array}$ & 1 & 2 & 3 & 4 & 5 & 6 & 7 \\
\hline $\begin{array}{l}\text { 9. Hayallerimde istediğim işin/mesleğin görüntüsü canlanıyor, ama } \\
\text { sanırım buna ulaşamayacağım. }\end{array}$ & 1 & 2 & 3 & 4 & 5 & 6 & 7 \\
\hline $\begin{array}{l}\text { 10.İstediğim kariyeri elde etme konusunda gerekli becerilere sahip } \\
\text { olduğumu düşünüyordum, fakat şimdilerde bundan emin değilim. }\end{array}$ & 1 & 2 & 3 & 4 & 5 & 6 & 7 \\
\hline $\begin{array}{l}\text { 11.Elde etmek istediğim kariyerin ne olduğunu biliyorum, fakat ona } \\
\text { ulaşmak için gerekli olan şeylere sahip olduğumu düşünmüyorum. }\end{array}$ & 1 & 2 & 3 & 4 & 5 & 6 & 7 \\
\hline $\begin{array}{l}\text { 12.Gerçekten elde etmek istediğim kariyer için gerekli olan şeyleri } \\
\text { karşılayabilme kapasitem olduğundan emin değilim. }\end{array}$ & 1 & 2 & 3 & 4 & 5 & 6 & 7 \\
\hline
\end{tabular}

Not: Bilimsel etik ve ilkelere bağlı kalmak koşuluyla araştırmacı ve eğitimciler tarafından kullanılması için izin alınmasına gerek yoktur. 